\title{
Shallow landslide prediction in the Serra do Mar, São Paulo, Brazil
}

\author{
B. C. Vieira ${ }^{1}$, N. F. Fernandes ${ }^{2}$, and O. A. Filho $^{3}$ \\ ${ }^{1}$ Department of Geography, University of São Paulo, São Paulo, Brazil \\ ${ }^{2}$ Department of Geography, Federal University of Rio de Janeiro, Rio de Janeiro, Brazil \\ ${ }^{3}$ Geotechnical Department, University of São Paulo, São Paulo, Brazil
}

Received: 31 January 2010 - Revised: 5 July 2010 - Accepted: 19 July 2010 - Published: 6 September 2010

\begin{abstract}
Various methods are currently used in order to predict shallow landslides within the catchment scale. Among them, physically based models present advantages associated with the physical description of processes by means of mathematical equations. The main objective of this research is the prediction of shallow landslides using TRIGRS model, in a pilot catchment located at Serra do Mar mountain range, São Paulo State, southeastern Brazil. Susceptibility scenarios have been simulated taking into account different mechanical and hydrological values. These scenarios were analysed based on a landslide scars map from the January 1985 event, upon which two indexes were applied: Scars Concentration ( $\mathrm{SC}$ - ratio between the number of cells with scars, in each class, and the total number of cells with scars within the catchment) and Landslide Potential (LP - ratio between the number of cells with scars, in each class, and the total number of cells in that same class). The results showed a significant agreement between the simulated scenarios and the scar's map. In unstable areas $(\mathrm{SF} \leq 1)$, the $\mathrm{SC}$ values exceeded $50 \%$ in all scenarios. Based on the results, the use of this model should be considered an important tool for shallow landslide prediction, especially in areas where mechanical and hydrological properties of the materials are not well known.
\end{abstract}

\section{Introduction}

Serra do Mar is a mountain range that extends for about $1500 \mathrm{~km}$ along the southeast coast of Brazil. The region has a great economic importance since it is crossed by the major land transportation network that connects the city of São Paulo to other large metro areas, as well as to the port of San-

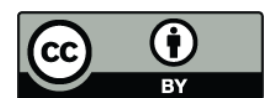

Correspondence to: B. C. Vieira (biancacv@usp.br) tos. The industrial region of Cubatão lies at the base of the Serra do Mar escarpment, and several industrial plants in the area have been affected by shallow landsliding and debris flows, especially during intense summer rainstorms. These have caused a severe impact on the infrastructure and significant social and economic damage (Kanji et al., 2008).

Mass movement events in Serra do Mar are known to occur in intervals of 5 to 10 years during the rainy season (Nalon, 2000) and, since the 1920s, there have been records of these processes, mainly debris flows and shallow landslides that caused several casualties and destroyed some of the local industrial plants (Meis and Silva, 1968; Barata, 1969; Costa Nunes, 1969; Jones, 1973; Vargas Jr. et al., 1986; Wolle and Hachich, 1989; Lacerda, 1997; Fernandes et al., 2004; Lacerda, 2007). In 1929, many landslides were triggered in the city of Santos, located on the foothills of Serra do Mar. Again, in 1956, the same region was affected as the accumulated rainfall reached the value of $373 \mathrm{~mm}$ in $24 \mathrm{~h}$, triggering 60 landslides almost simultaneously (IPT, 1986).

Between 17 and 18 March 1967, in the northern sector of Serra do Mar in São Paulo State, close to the municipality of Caraguatatuba, hundreds of landslides and major debris flows were generated during heavy rainfall $(580 \mathrm{~mm}$ in 2 days), approximately $35 \%$ of the total annual rainfall for that region. Likewise, on 23 and 24 January 1985, during an intense summer rainstorm ( $380 \mathrm{~mm}$ in 2 days), thousands of shallow landslides and debris flows were triggered (Figs. 1 and 2). In February 1994, some catchments on the Serra do Mar escarpment close to Cubatão were affected by landslides that reached the main tributary streams, increasing the magnitude of the debris flows. Kanji et al. (2008) estimated that the volume of the debris removed was about $300.000 \mathrm{~m}^{3}$ with an expected velocity of around $10 \mathrm{~m} / \mathrm{s}$, interrupting the Petrobrás oil refinery for about 3 weeks and leading to economic losses of about US\$ 40 million. Due to the landslide susceptibility in the Serra do Mar region and

Published by Copernicus Publications on behalf of the European Geosciences Union. 


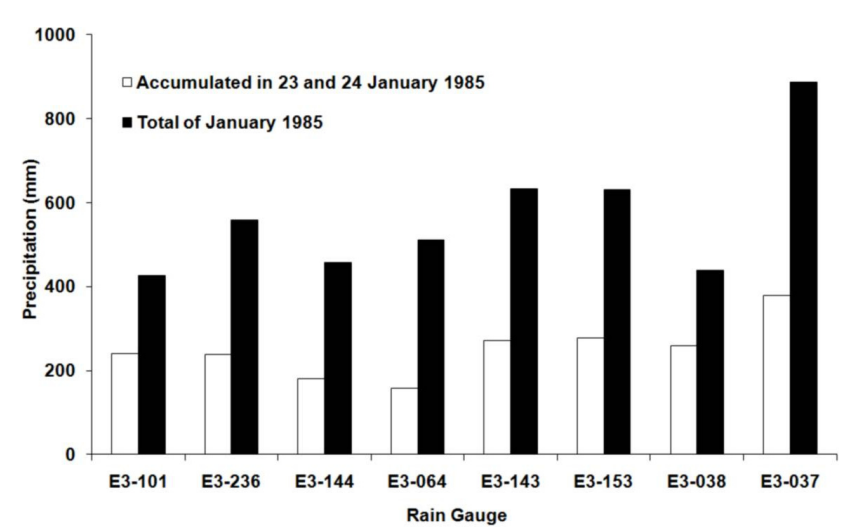

Fig. 1. Precipitation (mm) on 23 and 24 January 1985 registered by rain gauges in Serra do Mar, where in days many landslides were triggered.

the significant social and economical damages derived from it, it is important to understand the spatial and temporal distribution of these processes as well as the usage of prediction models, especially in the simulation of shallow landslides, the most common landslide type in the region.

Different methods and approaches have been developed and applied in landslides prediction. Some of them evaluated the role played by conditioning factors and triggering mechanisms in different environments and scales (e.g. Pachauri and Pant, 1992; Corominas et al., 2004; Hong et al., 2005). Other studies analysed the influence of external factors such as deforestation (e.g. Wu and Swanston, 1980; Preston and Crozier, 1999; Dhakal and Sidle, 2003) and climate change (e.g. Collison et al., 2000) which, in general, tend to affect hydrological dynamics and soil resistance, leading to an increased instability.

Various methods are currently used in space and time prediction of shallow landslides in a catchment scale. Among them, physically based models, such as dSLAM (Wu and Sidle, 1995; Dhakal and Sidle, 2003), SINMAP (Pack et al., 1998, 2001; Morrisey et al., 2001; Calcaterra et al., 2004), SHALSTAB (Dietrich et al., 1993, 1995; Montgomery and Dietrich, 1994; Montgomery et al., 1998), SHETRAN (Ewen et al., 2000) and TRIGRS (Iverson, 2000; Baum et al., 2002), present many advantages associated with the physical description of these processes from mathematical equations. The TRIGRS Model (Transient Rainfall Infiltration and Grid-Based Regional Slope-Stability) is a Fortran program, based on the association between a hydrologic and a stability model, that predict shallow landslides induced by rainfall events by computing transient pore-pressure changes and their effects on the Safety Factor at different depths (Baum et al., 2002).

This model has been applied to a variety of places inside the United States and abroad. Keim and Skaugset (2003), for example, used this model in order to characterise the potential effects of rainfall intensity smoothed by forest canopies

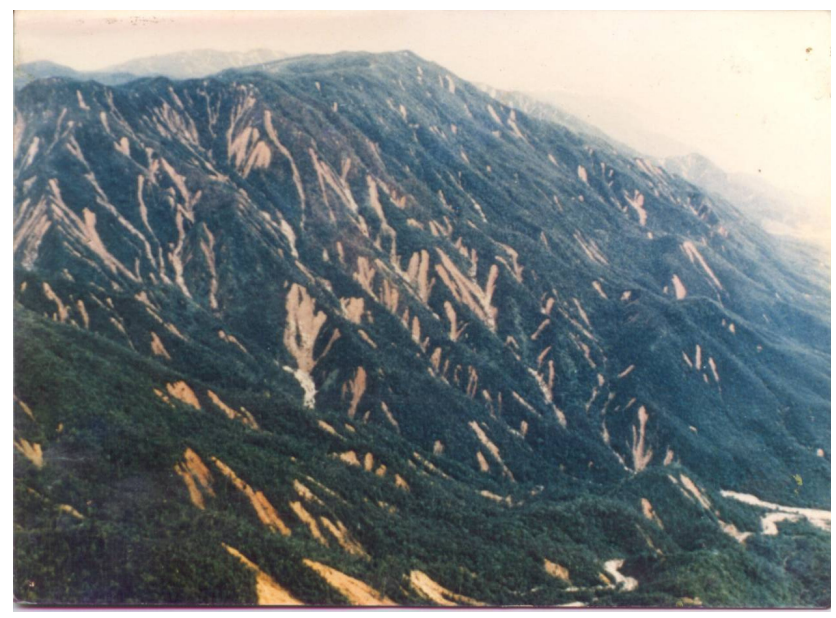

Fig. 2. Landslides triggered in Serra do Mar during a heavy rainfall $(379.4 \mathrm{~mm} / 48 \mathrm{~h})$ in 1985 . The occurrence of mass movements is common in this region, mainly shallow landslide types (Archive: Technology Research Institute of the São Paulo State/IPT).

on slope stability in the northeastern United States by modelling soil responses to measured rainfall and throughfall during high-intensity rainfall events. Chien-Yuan et al. (2005) used the TRIGRS model to analyse landslides induced by rainfall events in November 2000 in a region of Taiwan and observed that cracks in the soil and a surface rupture coincided with areas mapped as unstable by the model.

Baum et al. (2005) applied different models to investigate the mass movements frequently triggered in the area of Seattle and concluded that TRIGRS presented the best results. Savage et al. (2004), on the other hand, used the TRIGRS and SHALSTAB models and did not identify significant differences between the susceptibility maps generated by them. The spatial distribution of cells with a low critical rainfall value (more unstable) simulated by SHALSTAB mostly coincided with the location of areas with $\mathrm{SF} \leq 1$ generated by the TRIGRS model. The authors suggest that the great similarity between the outcomes obtained by the two models resulted from the major role played by topography in controlling landslide susceptibility in this area. The small differences observed were attributed to the fact that the TRIGRS model considered the spatial variation of soil depth, estimated from geotechnical and geological maps, while in SHALSTAB simulations this parameter was considered constant in the area. In a similar approach, Frattini et al. (2004) while trying to define susceptible areas in pyroclastic soils in Sarno (Italy), concluded that the TRIGRS model presented better results than the SHALSTAB model, predicting $70 \%$ and $60 \%$ of all landslide scars, respectively.

Considering the advantages of the TRIGRS model in the prediction of shallow landslides in steep areas during intense rainfall events, the main objective of this research consists on testing its ability on predicting unstable areas in the Serra 


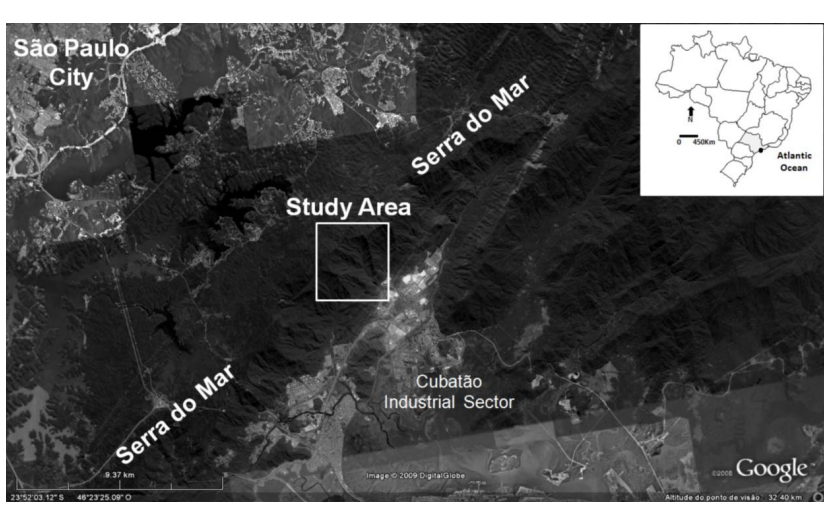

Fig. 3. Location of the study area (pilot catchment) in the Serra do Mar mountain range. On the base of this, in Cubatão region, there are many industries (Cubatão Industrial Sector). Some highways and railroads that pass through the Serra do Mar linking the city of São Paulo city to the port of Santos.

do Mar escarpment in the state of São Paulo. To attain this goal, a pilot catchment located close to Cubatão was selected and the hydrological conditions of the catastrophic event that took place in January 1985 (see description above) were simulated. It is believed that physically-based mathematical models, such as TRIGRS, have a potential to improve our understanding of hillslope failure mechanisms in areas such as the Serra do Mar escarpment, where the difficulty of access due to its steep slopes and dense tropical rainforest cover make direct field investigations not easily accomplished.

\section{Study area}

The Serra do Mar range is basically composed of PreCambrian metamorphic and igneous rocks consisting of a complex mixture of gneisses, granites, migmatites and biotite-schists. Hillslopes are very steep, often more than $35^{\circ}$, although locally in excess of more than $45^{\circ}$. The gentler slopes are covered by colluviums and talus deposits overlaying bedrock and residual soils. In general, steeper slopes show more resistant bedrock outcrops (e.g. granite) or are covered by thin soils, usually less than one metre thick.

The climate of this region is defined by a period of high rainfall (summer) alternated with a period of lower rainfall (winter). The rainy season occurs from December to March, and concentrates $60 \%$ of the average total annual precipitation. The average total annual rainfall for the most representative meteorological stations of the region, such as the rain gauge of Paranapiacaba, is about $3300 \mathrm{~mm}$. Although the original vegetation of the area was the Atlantic rainforest (Mata Atlântica), associated with the warm and moisty conditions of eastern coastal Brazil, due to the exposure of the study area slopes to intense air pollution in the 1970s and in 1980s the rainfall events of January 1985 occurred over degraded vegetation, dotted with a few forest relics. The study-site (Copebrás catchment), with an area of $3.6 \mathrm{~km}^{2}$, was selected due to the presence of shallow landslides (about 360 scars in the 1985 event), for being topographically representative of the region, as well as for its geographic position (upstream of the Industrial Complex of Cubatão) (Fig. 3). On January 1985, rain gauge stations, located in the region, recorded levels above $100 \mathrm{~mm}$ of rain per day. One, for example, located besides the Moji river, at $820 \mathrm{~m}$ a.s.l., recorded $379.4 \mathrm{~mm}$ in just $48 \mathrm{~h}$. Based on an analysis of the total rainfall for the month of January 1985 at several weather stations, it became evident that the rainfall event of 23 and 24 January accounted for more than $40 \%$ of the month's total, and in some stations this value reached above $60 \%$.

The catchment's physical aspects are characterised by a predominance of different types of migmatites, and the occurrence of biotite-schist at its base. Sixty percent of the hillslopes are between $400 \mathrm{~m}$ and $800 \mathrm{~m}$ of elevation, while $42 \%$ of the slope angles are between 30 and 40 degrees. Hillslopes are mostly towards SE, S and SW (about 64\%) and display predominantly convex and straight profiles (Fig. 4). Field investigations carried out in the area attested that most shallow landslide scars were about $1 \mathrm{~m}$ in depth (Wolle and Carvalho, 1989). These authors also identified two types of soil materials above the intensely fractured bedrock (a) colluvial soil (about $1 \mathrm{~m}$ depth) formed by pedogenesis over transported materials (mostly matrix-textured sandy clay and boulders of rocks), and (b) saprolite soil (about 3-4 m depth), more sandy than the overlying horizon as well as with evidences of structures inherited from bedrock.

\section{Methods}

Input topographical parameters to the TRIGRS model were generated from a high-resolution $\left(4 \mathrm{~m}^{2}\right)$ digital elevation model (DEM) obtained from a topographic map (1:10000 scale) and interpolated using the Topo to Raster module of ArcGis 9.1. The geotechnical and hydrological parameter were obtained from areas in the Serra do Mar with similar environmental characteristics and close to the pilot catchment. The values of angle of internal friction, cohesion and weight of soil used in this paper were obtained from studies conducted by Wolle and Carvalho (1989) in Serra do Mar. The authors performed laboratory tests on samples of mature colluvium and saprolite. The values of saturated vertical hydraulic conductivity were obtained in situ, by tests on soil samples of $10 \mathrm{~cm}$ and $5 \mathrm{~cm}$ in diameter, by using a falling head permeameter.

The values of rainfall intensity used in the TRIGRS model were extracted from the Information System for Water Resources Management of São Paulo State database. In order to select the most representative rain gauge to be used in this study, we considered the consistency of the data and a number of other parameters. For example, the location of the gauge in relation to the pilot catchment was considered particularly relevant because rainfall in Serra do Mar 

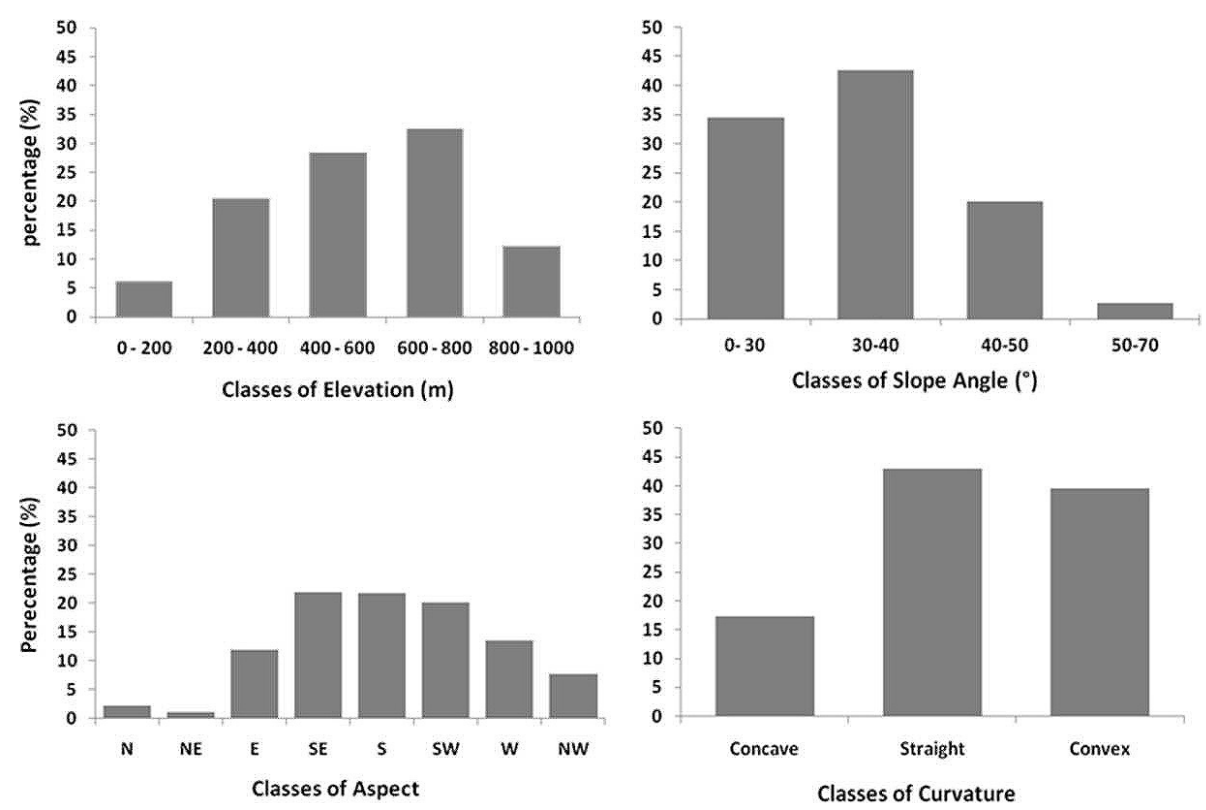

Fig. 4. Classes of topographic parameters (elevation, slope angle, aspect and curvature).

Table 1. Simulated scenarios by TRIGRS model.

\begin{tabular}{|c|c|c|c|c|c|c|}
\hline \multirow{2}{*}{$\begin{array}{l}\text { SCENARIOS } \\
\text { PARAMETERS [unit] }\end{array}$} & \multicolumn{3}{|c|}{ A (SATURATED) } & \multicolumn{3}{|c|}{ B (NATURAL) } \\
\hline & A1 & A2 & A3 & B1 & $\mathrm{B} 2$ & B3 \\
\hline Soil Cohesion $(c)[\mathrm{Pa}]$ & 1000 & 1000 & 1000 & 6000 & 6000 & 6000 \\
\hline Total unit weight of soil $\left(\rho_{\mathrm{s}}\right)\left[\mathrm{kN} / \mathrm{m}^{3}\right]$ & 17.1 & 17.1 & 17.1 & 14.3 & 14.3 & 14.3 \\
\hline Maximum depth $\left(Z_{\max }\right)[\mathrm{m}]$ & 1 & 2 & 3 & 1 & 2 & 3 \\
\hline Angle of internal friction $(\Phi)\left[{ }^{\circ}\right]$ & 34 & 34 & 34 & 34 & 34 & 34 \\
\hline Initial, steady depth of water table $(d)[\mathrm{m}]$ & 1 & 2 & 3 & 1 & 2 & 3 \\
\hline Steady, pre-storm infiltration rate $\left(I_{\mathrm{LT}}\right)[\mathrm{m} / \mathrm{s}]$ & $1.0 \times 10^{-9}$ & $1.0 \times 10^{-9}$ & $1.0 \times 10^{-9}$ & $1.0 \times 10^{-9}$ & $1.0 \times 10^{-9}$ & $1.0 \times 10^{-9}$ \\
\hline Hydraulic diffusivity $\left(D_{0}\right)\left[\mathrm{m}^{2} / \mathrm{s}\right]$ & $5.5 \times 10^{-4}$ & $5.5 \times 10^{-4}$ & $5.5 \times 10^{-4}$ & $5.5 \times 10^{-4}$ & $5.5 \times 10^{-4}$ & $5.5 \times 10^{-4}$ \\
\hline Vert. hydr. conductivity of sat. soil $\left(K_{\mathrm{S}}\right)[\mathrm{m} / \mathrm{s}]$ & $1.0 \times 10^{-6}$ & $1.0 \times 10^{-6}$ & $1.0 \times 10^{-6}$ & $1.0 \times 10^{-6}$ & $1.0 \times 10^{-6}$ & $1.0 \times 10^{-6}$ \\
\hline
\end{tabular}

is strongly influenced by topography. In the same way, the weather series should also cover the period when the landslide events occurred (22 and 23 January 1985). Rainfall intensity and cumulative duration values used in this study were the following: $5.4 \times 10^{-7} \mathrm{~m} / \mathrm{s}(0 \mathrm{~h}), 1.7 \times 10^{-6} \mathrm{~m} / \mathrm{s}(6 \mathrm{~h})$ and $6.0 \times 10^{-6} \mathrm{~m} / \mathrm{s}(12 \mathrm{~h})$. The $0 \mathrm{~h}$ is the starting time of rainfall.

In the simulations carried out in this study, homogeneous conditions were considered due to the lack of information concerning the spatial variability of soil properties. Two groups of scenarios were simulated: A Scenarios - in which the same values of soil cohesion $(1 \mathrm{kPa})$ and unit weight $\left(17.1 \mathrm{kN} / \mathrm{m}^{3}\right)$ were used under saturated conditions; B Scenarios - in which other values of cohesion $(6 \mathrm{kPa})$ and weight of soil $\left(14.3 \mathrm{kN} / \mathrm{m}^{3}\right)$ were used under unsaturated conditions. For each group of scenarios, another three subgroups were created with different values of soil thickness (e.g. Scenario A1 $=1 \mathrm{~m}$ (soil thickness), Scenario A2 $=2 \mathrm{~m}$ (soil thickness) and Scenario A3 $=3 \mathrm{~m}$ (soil thickness)) and, initial depth of the water table $(\mathrm{A} 1=1 \mathrm{~m}$, $\mathrm{A} 2=1 \mathrm{~m}$ and $\mathrm{A} 3=1 \mathrm{~m})$. The common constant values used in all simulated scenarios are: angle of internal friction $\left(34^{\circ}\right)$, steady infiltration rate $\left(1.0 \times 10^{-9} \mathrm{~m} / \mathrm{s}\right)$, hydraulic diffusivity $\left(5.5 \times 10^{-4} \mathrm{~m}^{2} / \mathrm{s}\right)$ and vertical hydraulic conductivity of saturated soil $\left(1.0 \times 10^{-6} \mathrm{~m} / \mathrm{s}\right)$. Table 1 presents a summary of the values used in simulations.

Landslide scars were mapped on 1:25000 aerial photographs to delineate polygons where landslides occurred. Within the criteria set for this mapping, the delimitation of the scars was made only on the lighter patches with more contrast in texture, without vegetation. However, the orthophoto presents some intermediate textures between the dense vegetation and the scars. These have been interpreted either as being older scars (prior to 1985), or as areas that 
had a more rapid vegetative recovery after the 1985 event. Therefore, these features were not considered as landslide scars in order to guarantee that the final map is only relative to the 1985 event. The simulated scenarios were evaluated based on an analysis of agreement between predicted susceptibility and the landslide scar's map, using two indexes: Scars Concentration (SC) which is the ratio between the number of cells with scars, in each class of SF (Safety Factor), and the total number of cells with scars in the catchment and, the Landslide Potential (LP) which is the ratio between the number of cells with scars, in each class of SF, and the total number of cells of that same class of SF (Safety Factor). Using only the susceptibility map, the Frequency ( $\mathrm{F} \%$ ) index of the SF classes was calculated.

To use the TRIGRS model, some values must be chosen in order to define the Safety Factor (SF). In this paper, we used the value indicated by Baum et al. (2002) for calculating the hydrological routine (TopoIndex), assuming, therefore, that water flows down the steepest slope. It calculates the direction of the steepest slope and attempts to direct flow in that direction by partitioning the flow between the two cells nearest to the steepest slope direction. The shallowest depth, at which it computes pore pressures, was equal to $0.1 \mathrm{~m}$ and it was considered that hydraulic properties are uniform with depth (Iverson, 2000). Therefore, the susceptibility maps were generated considering the minimum value of Safety Factor (SF) computed in each cell.

\section{Results and discussion}

We mapped 356 scars from the 1985 event, occupying an area of $132.672 \mathrm{~m}^{2}$ and representing about $3.7 \%$ of the total area of the catchment, with most of the scars (about 60\%) presenting an area of less than $300 \mathrm{~m}^{2}$. The biggest mapped scar has an area of $2.704 \mathrm{~m}^{2}$ while the smallest only $11 \mathrm{~m}^{2}$, with an average area for the scars of about $373 \mathrm{~m}^{2}$.

The A1, A2 and A3 scenarios showed little variations in the spatial distribution of the SF classes (Figs. 5, 6, and 7). The change of soil thickness from $1 \mathrm{~m}$ (A1) to $2 \mathrm{~m}$ (A2) increased the percentage of unstable areas to about $10 \%$. In all these scenarios the Frequency $(\mathrm{F})$ of stable areas $(\mathrm{SF}>1)$ were: $67 \%$ (A1 scenario), 60\% (A2 scenario) and $57 \%$ (A3 scenario) and all these stable areas were mainly located on convex and gentle slopes, with angles smaller than $30^{\circ}$. The simulations indicate that the unstable areas $(\mathrm{SF} \leq 1)$ were: $33 \%$ (A1 scenario), $40 \%$ (A2 scenario) and $43 \%$ (A3 scenario) and were located mainly on higher elevations $(>400 \mathrm{~m})$ and steeper slopes $\left(>40^{\circ}\right)$.

The correlation between the susceptibility maps generated by the TRIGRS model and the scar's map was analysed through the Scars Concentration (SC) and the Landslides Potential (LP) indexes and is shown in Fig. 8. The behaviour of these indexes was very similar in A1, A2, and A3 scenarios,

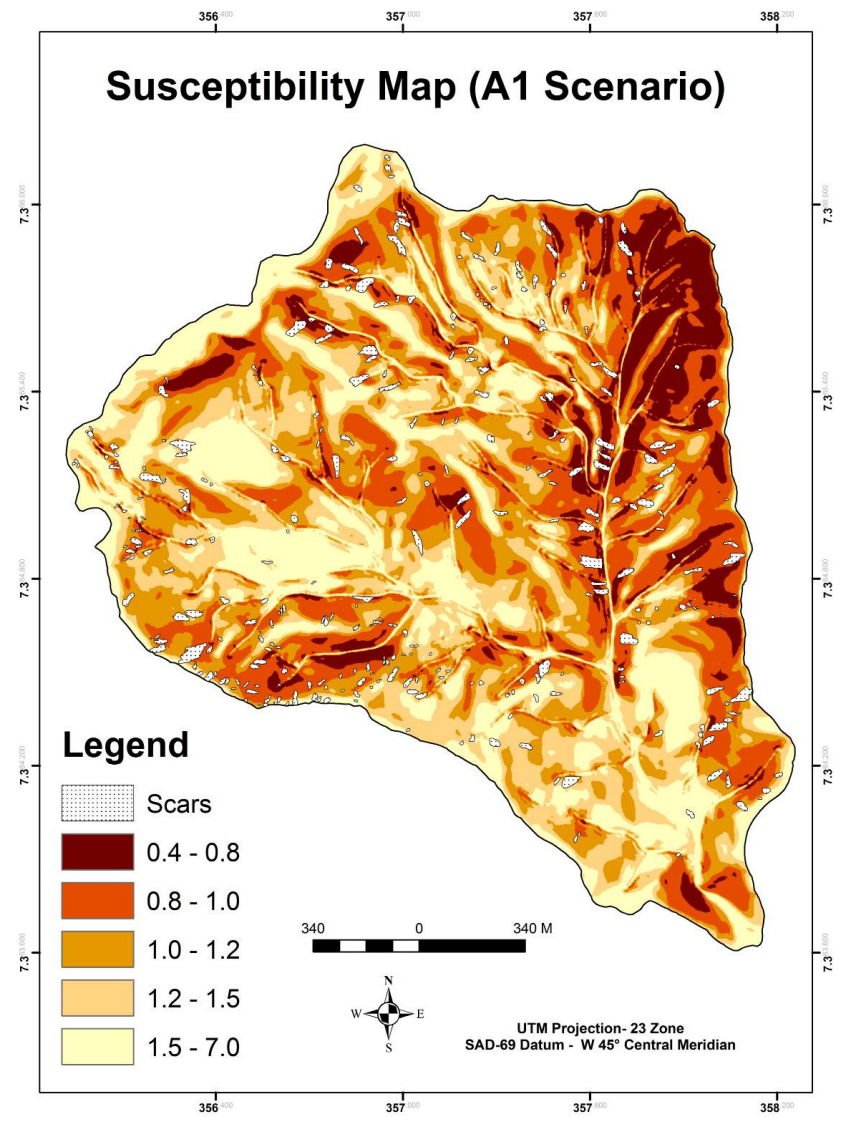

Fig. 5. The susceptibility map of the shallow landslides (SF). In Scenario A1 we used the values: soil cohesion $(1000 \mathrm{~Pa})$, weight unit $\left(17.1 \mathrm{kN} / \mathrm{m}^{3}\right)$, soil thickness $(1 \mathrm{~m})$, initial depth of the water table $(1 \mathrm{~m})$, angle of internal friction $\left(34^{\circ}\right)$, steady infiltration rate $\left(1.0 \times 10^{-9} \mathrm{~m} / \mathrm{s}\right)$, hydraulic diffusivity $\left(5.5 \times 10^{-4} \mathrm{~m}^{2} / \mathrm{s}\right)$ and vertical hydraulic conductivity of saturated soil $\left(1.0 \times 10^{-6} \mathrm{~m} / \mathrm{s}\right)$.

in all SF classes. Most unstable classes showed the highest values of LP (between 5.0\% and 6.4\%). The increase of SF values was followed by the decrease in LP, which reached values smaller than $1 \%$.

In the unstable areas $(\mathrm{SF} \leq 1)$, the values of $\mathrm{SC}$ exceeded $50 \%$ in all scenarios $(53 \%, 62 \%$, and $66 \%$ in $\mathrm{A} 1, \mathrm{~A} 2$, and A3 scenarios, respectively). This behaviour was very similar that others presented in the literature using TRIGRS model. Crosta and Frattini (2003), in a basin in Lecco province (Italy), predicted $17.5 \%$ of unstable areas, while concentrated $72.3 \%$ of scars mapped and Salciarini et al. (2006), in the Umbria region (Italy), $78 \%$ of the scars mapped were predicted by the model. In studies developed by Bisanti et al. (2005), although this model has predicted only $12.6 \%$ of the unstable areas $(\mathrm{SF}<1)$, about $41 \%$ of the total landslides were located in this SF class.

When these results are compared, what can be observed is a variation between the percentage of the scar concentration and the unstable areas predicted. In this paper, although 


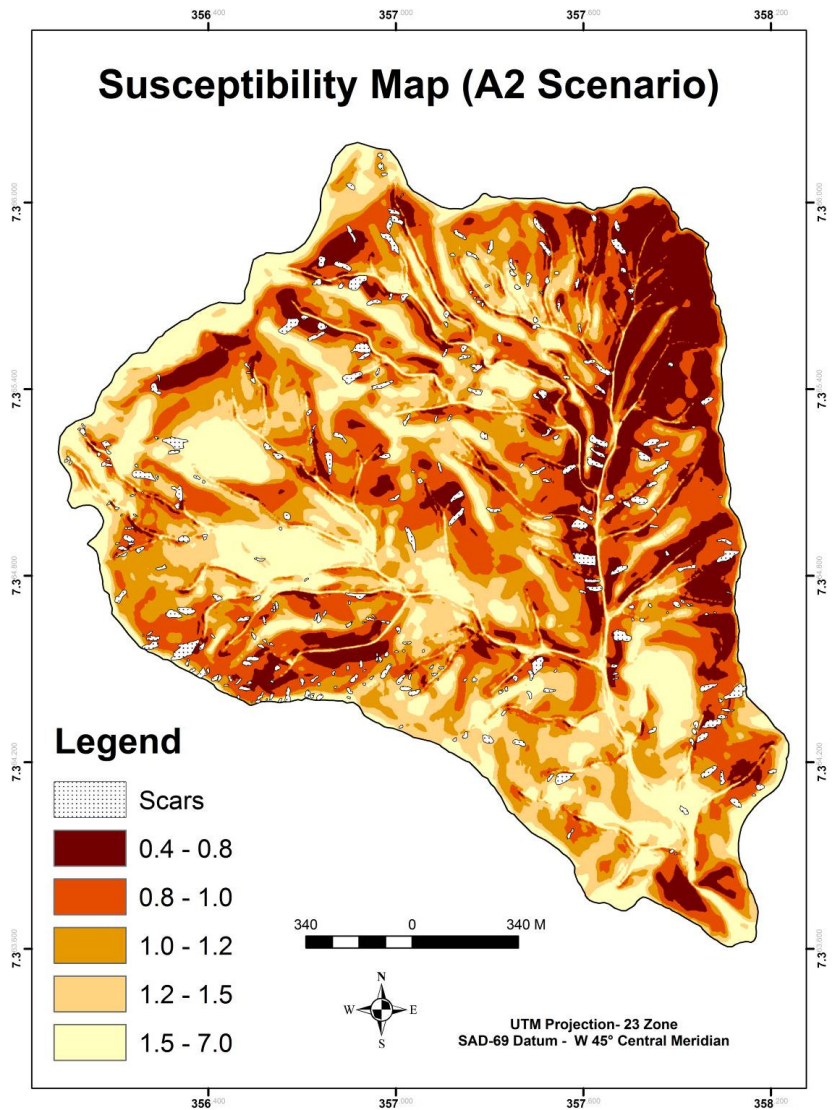

Fig. 6. The susceptibility map of the shallow landslides (SF). In Scenario A2 we used the values: soil cohesion (1000 Pa), weight unit $\left(17.1 \mathrm{kN} / \mathrm{m}^{3}\right)$, soil thickness $(2 \mathrm{~m})$, initial depth of the water table $(2 \mathrm{~m})$, angle of internal friction $\left(34^{\circ}\right)$, steady infiltration rate $\left(1.0 \times 10^{-9} \mathrm{~m} / \mathrm{s}\right)$, hydraulic diffusivity $\left(5.5 \times 10^{-4} \mathrm{~m}^{2} / \mathrm{s}\right)$ and vertical hydraulic conductivity of saturated soil $\left(1.0 \times 10^{-6} \mathrm{~m} / \mathrm{s}\right)$.

more than $50 \%$ of the scars had coincided with the unstable areas, the Frequency (F) of unstable areas was higher than what was found in these papers cited. This fact may be related to the values of soil properties, since in most studies that use the model TRIGRS, the values of cohesion, friction angle and hydraulic conductivity, for example, are obtained directly from field investigations, improving the accuracy of the frequency of the unstable areas in susceptibility maps (e.g. Crosta and Frattini, 2003; Salciarini et al., 2006).

The changes of the geotechnical and hydrological parameters, especially soil cohesion, caused significant changes in the susceptibility maps and in the percentage of the SF classes. There was a considerable increase in the percentage of stable areas in the three scenarios, with prominence on the B1 scenario (100\% stable slopes). In the B1 scenario, the stable areas occupied $100 \%$ of the catchment. In the B2 and B3 scenarios this index was $97 \%$ and $87 \%$, respectively. Consequently, there was a proportional reduction of the un-

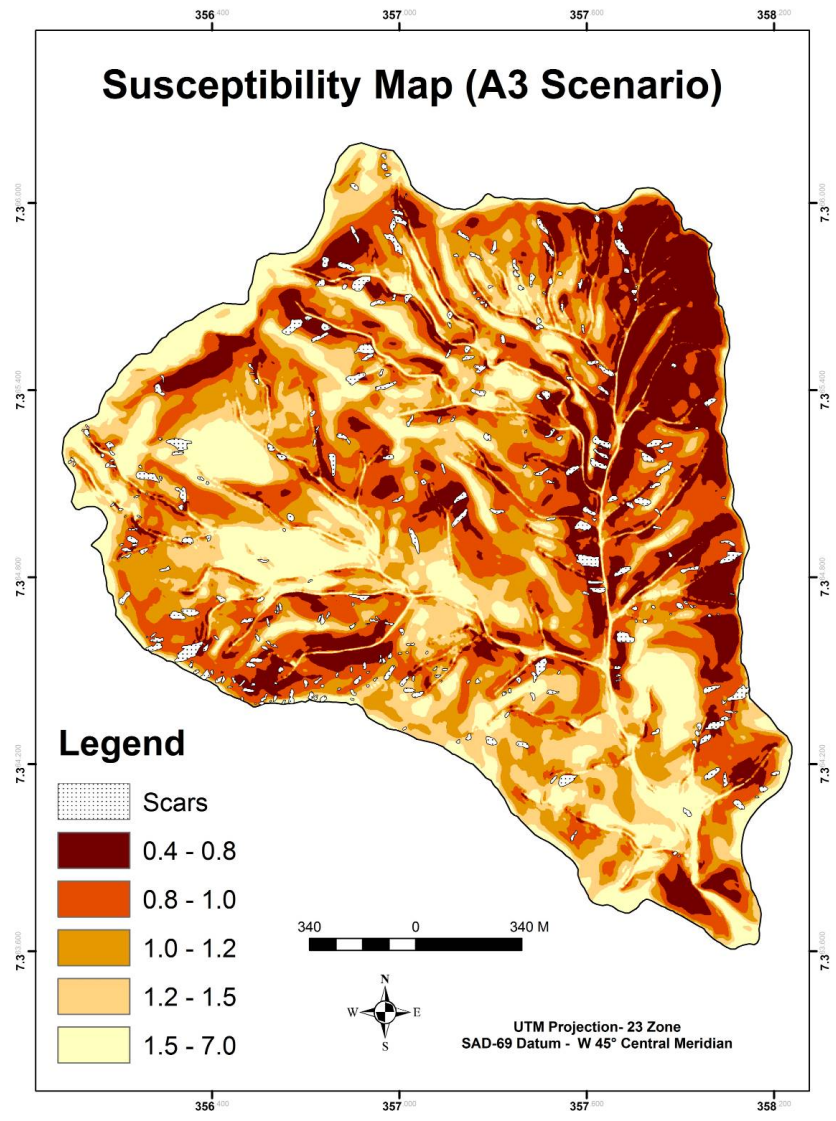

Fig. 7. The susceptibility map of the shallow landslides (SF). In Scenario A3 we used the values: soil cohesion (1000 Pa), weight unit $\left(17.1 \mathrm{kN} / \mathrm{m}^{3}\right)$, soil thickness $(3 \mathrm{~m})$, initial depth of the water table $(3 \mathrm{~m})$, angle of internal friction $\left(34^{\circ}\right)$, steady infiltration rate $\left(1.0 \times 10^{-9} \mathrm{~m} / \mathrm{s}\right)$, hydraulic diffusivity $\left(5.5 \times 10^{-4} \mathrm{~m}^{2} / \mathrm{s}\right)$ and vertical hydraulic conductivity of saturated soil $\left(1.0 \times 10^{-6} \mathrm{~m} / \mathrm{s}\right)$.

stable areas, which occupied only 3\% (B2) and 13\% (B3). However, even with the considerable reduction of the unstable area percentages, the spatial distribution has not changed, probably due to the substantial topographic control.

The difference between the scenarios A and B were expected mainly due to the increase in the value of soil cohesion. However, only with the validation of these scenarios, using SC and LP, was possible to assess the degree of accuracy. In analysing the Landslides Potential (LP), it was observed that in the unstable classes (SF between 0.4 and 0.8) the values were below $2 \%$ in all three scenarios. However, it is emphasized, that the second class (SF between 0.8 and 1.0), showed significant index value, especially in B3 scenario $(5.7 \%)$. These values show that, even occupying an area not very representative in the catchment, only 3\% (B2) and $12 \%$ (B3), this class was affected by landslides. 

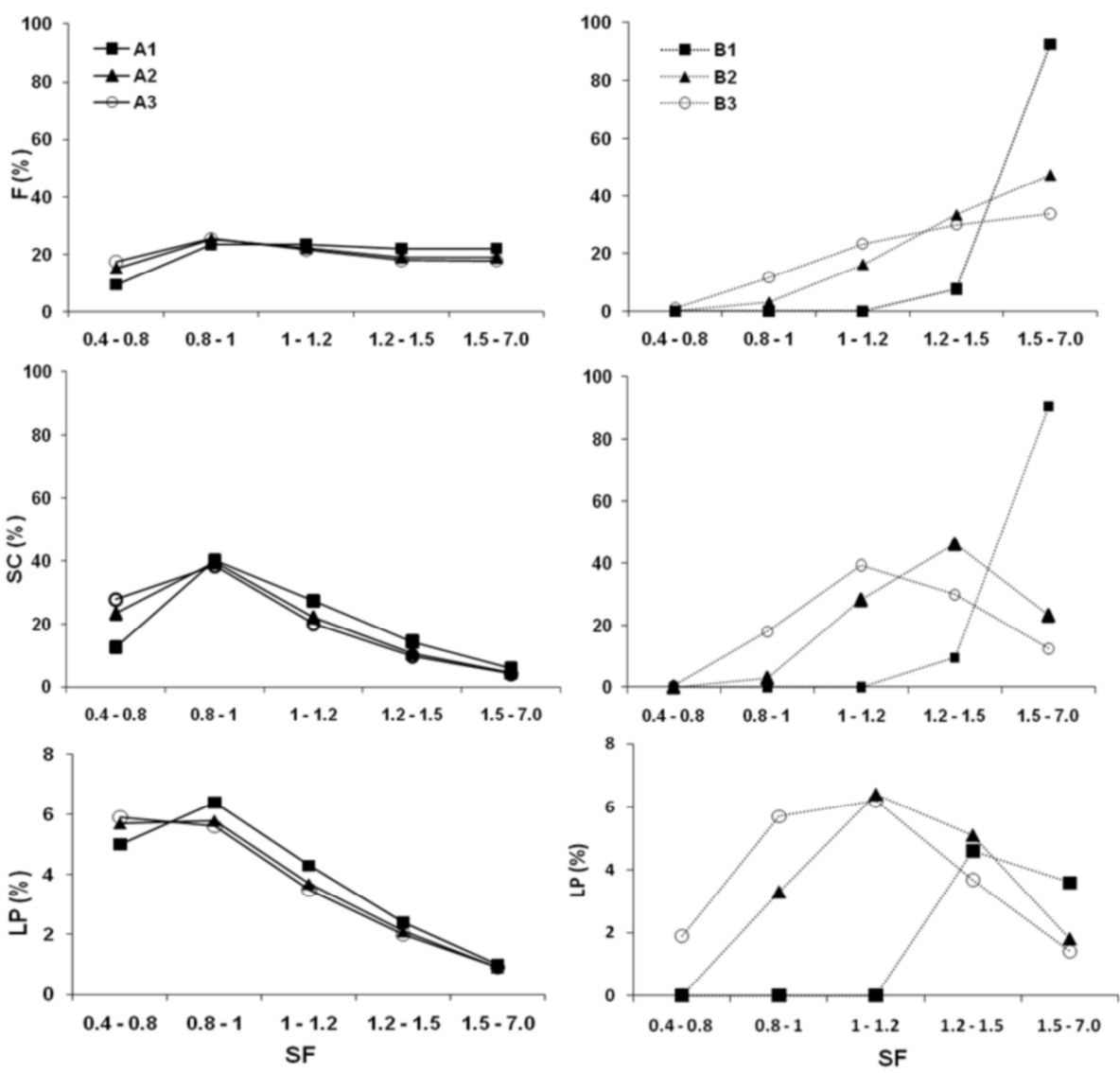

Fig. 8. Frequency (F), Scars Concentration (SC) and the Landslide Potential (LP) indexes for the Safety Factor (SF) for A1, A2, A3, B1, B2, and $\mathrm{B} 3$ scenarios.

\section{Conclusions}

It was possible to demonstrate that the use of physically based models provide important information for understanding the landslides spatial distribution. On most susceptibility maps there was a significant correlation between the unstable areas predicted and landslides mapped.

The scars map was sufficient for the validation of susceptibility maps. The use of the SC and LP indexes demonstrated that the model showed satisfactory results. In many studies, it is common to use only SC that can modify the interpretation of the effectiveness of susceptibility maps because there is a tendency to increase this index with the expansion of unstable areas. On the other hand, the use of the LP index can be more consistent in the scars distribution in each susceptibility class. However, it is still necessary mapping other events, associated with rainfall, to validate and understand the relationship between rainfall events and landslides in the Serra do Mar. In this area, these models can simulate susceptibility scenarios, considering different types of human activities and, when combined with debris flow models, can identify the volume of material available for the generation of these processes. Records of past events in the region shows that debris flows reached the Industrial Pole (Cubatão city), causing numerous social and economic damages.

Acknowledgements. This research was supported by FAPESP (São Paulo State Research Foundation) and CNPq (Brazilian National Research Council). The authors thank the following colleagues for continuing support and discussion: Lis Maria Rabaco, Eymar Silva Sampaio Lopes, Paulina Setti Riedel, Ligia Vizeu Barrozo, Emerson Galvani, Eurípedes do Amaral Vargas Jr., Maria Naíse de Oliveira Peixoto, André de Souza Avelar, Antonio Carlos de Barros Corrêa, Roberto Arnaldo Trancoso Gomes and Willian Santos. The discussions on landslide processes with researchers from IPT (Technology Research Institute of the São Paulo State) were really appreciated. We also thank COPEBRÁS Company for allowing the access to the study area. This manuscript was significantly improved by the contributions made by two anonymous reviewers.

Edited by: M. Pastor

Reviewed by: two anonymous referees 


\section{References}

Barata, F. E.: Landslides in the Tropical Region of Rio de Janeiro, 7th International Conference on Soil Mechanics and Foundation Engineering, Mexico, 1969.

Baum, R. L., Coe, J. A., Godt, J. W., Harp, E. L., Reid, M. E., Savage, W. Z., Shulz, W. H., Brien, D. L., Chleborad, A. F., MacKenna, J. P., and Michel, J. A.: Regional landslide-hazard assessment for Seattle, Washington, USA, Landslides, 2, 266279, 2005.

Baum, R. L., Savage, W. Z., and Godt, J. W.: TRIGRS: A FORTRAN program for transient rainfall infiltration and grid-based regional slope-stability analysis, USGS, Colorado, Open-file Report 02-424, 35 pp., 2002.

Bisanti, B., Molnar, P., and Burlando, P.: Predicting rainfall triggered soil slips: a case study in the Emmental Region (Switzerland), in: 3rd Swiss Geosciences Meeting, Zurich, 1-2, 18-19 November 2005.

Calcaterra, D., Riso, R., and Di Martire, D.: Assessing shallow debris slide hazard in the Agnano Plain (Naples, Italy) using SINMAP, a physically based slope-stability model, in: Landslides: evaluation and stabilization, edited by: Lacerda, W., Ehrlich, M., Fontoura, S. A. B., and Sayão, A. S. F., Taylor \& Francis Group, Rio de Janeiro, 177-183, 2004.

Chien-Yuan, C., Tien-Chien, C., Fan-Chieh, Y., and Sheng-Chi, L.: Analysis of time-varying rainfall infiltration induced landslide, Environ. Geol., 48, 466-479, 2005.

Collison, A., Wade, S., Griffiths, J., and Dehn, M.: Modelling the impact of predicted climate change on landslide frequency and magnitude in SE England, Eng. Geol., 55, 205-218, 2000.

Corominas, J., Moya, J., Masachs, I., Baeza, C., and Hürlimann, M.: Reconstructing recent activity of Pyrenean landslides by means of dendrogeomorphological techniques, in: Landslides: evaluation and stabilization, edited by: Lacerda, W., Ehrlich, M., Fontoura, S. A. B., and Sayão, A. S. F., Taylor \& Francis Group, Rio de Janeiro, 363-369, 2004.

Costa Nunes, A. J.: Landslides in soils of decomposed rock due to intense rainstorms, 7th International Conference on Soil Mechanics and Foundation Engineering, Mexico, 1969.

Crosta, G. B. and Frattini, P.: Distributed modelling of shallow landslides triggered by intense rainfall, Nat. Hazards Earth Syst. Sci., 3, 81-93, doi:10.5194/nhess-3-81-2003, 2003.

Dhakal, A. S. and Sidle, R.: Long-term modeling of landslides for different forest managent practices, Earth Surf. Proc. Land., 28, 853-868, 2003.

Dietrich, W. E., Reiss, R., Hsu, M. L., and Montgomery, D. R.: A Process-based model for colluvium soil depth and shallow landsliding using digital elevation data, Hydrol. Process., 9, 383-400, 1995.

Dietrich, W. E., Wilson, C. J., Montgomery, D. R., and McKean, J.: Analysis of erosion thresholds, channel networks and landscape morphology using a digital terrain model, J. Geol., 101, 259-178, 1993.

Ewen, J., Parkin, G., and O'Connell, P. E.: SHETRAN: distributed river basin flow and transport modeling system, J. Hydrol. Eng., 5, 250-258, 2000.

Fernandes, N. F., Guimarães, R. F., Gomes, R. A. T. ; Vieira, B. C., Montgomery, D. R., and Greenberg, H.: Topographic Controls of Landslides in Rio de Janeiro: Field Evidences and Modeling. Catena, Amsterdam, 55, 163-181, 2004.
Frattini, P., Crosta, G. B., Fusi, N., and Negro, P. D.: Shallow landslides in pyroclastic soils: a distributed modelling approach for hazard assessment, Eng. Geol., 73, 277-295, 2004.

Godt, J. W., Baum, R. L., and Chleborad, A. F.: Rainfall characteristics for shallow landsliding in Seattle, Washington, EUA, Earth Surf. Proc. Land., 31, 97-110, 2006.

Hong, Y., Hiura, H., Shino, K., Sassa, K., Suemine, A., Fukoaka, H., and Wang, G.: The influence of intense rainfall on the activity of large-scale crystalline schist landslides in Shikoku, Japan, Landslides, 2, 97-105, 2005.

IPT (Technology Research Institute of the São Paulo State): Indicação preliminar de áreas prioritárias para recomposição da cobertura vegetal na serra do mar na área de Cubatão, Report, São Paulo, 1986 (in Portuguese).

Iverson, R. M.: Landslide triggering by rain infiltration, Water Resour. Res., 36, 1897-1910, 2000.

Jones, F. O.: Landslides of Rio de Janeiro and the Serra das Araras Escarpment, Brazil, US Geological Survey. Prof. Paper 697, 42 pp., 1973.

Kanji, M. A., Cruz, P. T., and Massad, F.: Debris flow affecting the Cubatão Oil Refinery, Brazil, Landslides, 5, 71-82, 2008.

Keim, R. F. and Skaugset, A. E.: Modelling effects of forest canopies on slope stability, Hydrol. Process., 17, 1457-1467, 2003.

Lacerda, W. A.: Landslide initiation in saprolite and colluvium in southern Brazil: Field and laboratory observations, Geomorphology, 87(3), 104-119, 2007.

Lacerda, W. A.: Stability of Natural Slopes Along the Tropical Coast of Brazil, Proceeding of the International Symposium on Recent Developments in Soil and Pavement Mechanics, M. Almeida, Brookfield, 17-39, 1997.

Massad, F., Cruz, P. T., and Kanji, M. A.: Comparison between estimated and measured debris flow discharges and volume of sediments, in: 2nd Pan-American Symposium on Landslides, Rio de Janeiro, 213-222, 10-14 November 1997.

Meis, M. R. M. and Silva, J. X.: Mouvements de masse récents, à Rio de Janeiro: Une étude de géomorphologie dynamique, Revue de Géomorphologie Dynamique 18, 145-152, 1968.

Montgomery, D. R. and Dietrich, W. E.: A physically based model for the topographic control on shallow landsliding, Water Resour. Res., 30(4), 1153-1171, 1994.

Montgomery, D. R., Sullivan, K., and Greenberg, H. M.: Regional test of a model for shallow landsliding, Hydrol. Process., 12, 943-955, 1998.

Morrisey, M. M., Wieczorek, G. F., and Morgan, B. A.: A comparative analysis of hazard models for predicting debris flows in Madison County, Virginia, USGS, Open-File Report 01-0067, 2001.

Nalon, M. A.: Mapeamento de risco de escorregamento na região de Cubatão, SP, Mapeamento de risco de escorregamento na região de Cubatão, SP, Ph.D. thesis, Universiy of São Paulo, Piracicaba, 147 pp., 2000 (in Portuguese).

Pachauri, A. K. and Pant, M.: Landslide hazard mapping based on geological attributes, Eng. Geol., 32, 81-100, 1992.

Pack, R. T., Tarboton, D. G., and Goodwin, C. N.: Assessing terrain stability in a GIS using SINMAP, in: 15th annual GIS conference, GIS 2001, Vancouver, 56-68, 19-22 February 2001.

Pack, R. T., Tarboton, D. G., and Goodwin, C. N.: Terrain stability mapping with SINMAP, Technical description and users guide 
for version 1.00, Report and software available at: http://www. engineering.usu.edu/dtarb/ (last access: 15 June 2007), 1998.

Preston, N. J. and Crozier, M. J.: Resistance to shallow landslide failure through root-derived cohesion in east coast hill country soils, North Island, New Zealand, Earth Surf. Proc. Land., 24, 665-675, 1999.

Salciarini, D., Godt, J. W., Savage, W. Z., Conversini, P., Baum, R. L., and Michael, J. A.: Modeling regional initiation of rainfallinduced shallow landslides in the eastern Umbria Regional of Central Italy, Landslides, 3, 181-194, 2006.

Savage, W. Z., Godt, J. W., and Baum, R. L.: Modeling timedependent areal slope stability, in: Landslides: Evaluation Stabilization, edited by: Lacerda, W., Ehrlich, M., Fontoura, S. A. B., and Sayão, A. S. F., Taylor \& Francis Group, Rio de Janeiro, 23-36, 2004.
Vargas Jr., E., Oliveira, A. R. B., Costa Filho, L. M., and Campos, T. P.: A study of the relationship between the stability of slopes in residual soils and rain intensity, International Symposium on Environmental Geotechnology, Envo Publishing, Leigh, USA, 491-500, 1986.

Wolle, C. M. and Carvalho, C. S.: Deslizamentos em encostas na Serra do Mar-Brasil, Solos e Rochas, 27-36, 1989.

Wolle, M. C. and W. Hachich, W.: Rain-induced landslides in southeastern Brazil, 12th Int. Conf. on Soil Mech. and Found. Eng., Rio de Janeiro Brasil, 1989.

$\mathrm{Wu}, \mathrm{T}$. H. and Swanston, D. N.: Risk of landslides in shallow soils and its relation to clearcutting in southeastern Alaska, Forest Sci. 26, 495-510, 1980.

Wu, W. and Sidle, R. C.: A distributed slope stability model for steep forested basins, Water Resour. Res., 31, 2097-2110, 1995. 